\title{
Bổ sung dẫn liệu phân tử và khảo sát đặc điểm nuôi trồng của chủng nấm Hương Sapa Lentinula edodes
}

\section{Supplementation of molecular data and studying the cultural characteristics of Sapa shiitake mushroom Lentinula edodes}

\author{
Lê Huyền Ái Thúy ${ }^{1}$, Lao Đức Thuận ${ }^{1}$, Nguyễn Hoàng Mai ${ }^{2}$, Phan Hoàng Đại ${ }^{2}$, \\ Nguyễn Trương Kiến Khương ${ }^{2}$, Trương Bình Nguyên ${ }^{2 *}$ \\ ${ }^{1}$ Trường Đại học Mở Thành phố Hồ Chí Minh, Việt Nam \\ ${ }^{2}$ Đại học Đà Lạt, Việt Nam \\ *Tác giả liên hệ, Email: nguyentb@dlu.edu.vn
}

\section{THÔNG TIN}

DOI: $10.46223 / \mathrm{HCMCOUJS.}$ tech.vi.16.1.1915.2021

Ngày nhận: 04/06/2021

Ngày nhận lại: 07/06/2021

Duyệt đăng: 15/06/2021

\section{Tù khóa:}

hình thái giải phẫu; ITSrDNA; giống nấm; Lentinula edodes; Sapa

\section{TÓM TẮT}

Mẫu nấm Hương Sapa (Ký hiệu Len026) được thu hái tại vùng rừng núi xã Sơn Bình, huyện Tam Đường, tỉnh Lào Cai vào cuối tháng 05 năm 2019 khi đang phát triển trên các thân cây lá rộng mục. Các đặc điểm hình thái bên ngoài như màu nâu đỏ (khi ẩm ướt) chuyển sang vàng nâu, kèm các vết nứt nhẹ (khi khô) của mũ nấm cùng các vảy sợi trên bề mặt mũ, lớp thịt mũ mỏng, mép mũ cuộn khi non duỗi phẳng đến hơi vểnh lên khi già; Các đặc điểm hiển vi như cấu tạo dạng elip của bào tử và đặc biệt là sự tồn tại của các liệt bào cạnh (pleurocystidia) và liệt bào đỉnh (cheilocystidia) cho thấy mẫu nấm này mang khá nhiều đặc điểm pha trộn của cả 03 loài Lentinula edodes, Lentinula lateritia và Lentinula boryana, là những loài loài đã được nhận định có thể tồn tại ở nước ta. Tuy nhiên, các dẫn liệu phân tích đoạn ITS rDNA cho mẫu nấm Hương trên lại cho thấy đây là loài Lentinula edodes. Giống thuần của chủng nấm này đã được phân lập từ mô thịt quả thể. Trong điều kiện nuôi trồng nhân tạo trên cơ chất mạt cưa gỗ cao su nấm sinh trưởng và phát triển rất tốt. Mặc dù hiệu suất sinh học của chủng Len026 còn khá thấp nhưng với các đặc điểm như: tốc độ tăng trưởng hệ sợi và quá trình nâu hóa hệ sợi nhanh cũng như khả năng hình thành mầm nấm rất mạnh cho thấy đây là một chủng nấm tiềm năng dùng làm nguyên liệu lai tạo giống nấm mới phục vụ công nghệ nuôi trồng nấm Hương của địa phương.

\section{ABSTRACT}

Samples of Sapa shiitake mushroom (named Len026), growing on decaying broadleaf stems, were collected in the mountainous areas of Son Binh commune, Tam Duong district, Lao Cai province at the end of May 2019. External morphological features: the mushroom cap has fibrous scales on its surface, reddish brown (when being wet) turn into yellow brown, with 
Keywords:

anatomical morphology; ITS rDNA; Lentinula edodes; mushroom varieties; Sapa slight cracks (when being dry); thin cap flesh; in young fruiting bodies, rolled cap edge, flattened to slightly raised in mature ones. Microscopic features the elliptic structure of the spores and especially the existence of pleurocystidia and cheilocystidia. The above features indicate that this sample has quite a mix of all three characteristics species Lentinula edodes, Lentinula lateritia and Lentinula boryana, which have been identified that may exist in our country. However, the ITS rDNA analysis data for this mushroom shows that this is a species of Lentinula edodes. Purebred of this strain has been isolated from fruiting body tissue. In the conditions of artificial cultivation on the rubber wood sawdust substrate, the mushroom grew and developed very well. Although the biological efficiency of strain Len026 was still quite low, the characteristics such as: rapid growth of mycelium and browning of mycelium as well as the ability to form very strong fungal sprouts indicate that this strain is potential to be used as a raw material for breeding new mushroom varieties for local technology of growing shiitake mushrooms.

\section{Giới thiệu}

Nấm hương Lentinula edodes (Berk.) Pegler thuộc họ Marasmiaceae bộ Agaricales, tên người Tày gọi là bioóc hom (nấm hoa). Theo các nghiên cứu về khu hệ tài nguyên nấm hương Lentinula trên thế giới thì Việt Nam nằm trong khu vực phân bố của năm trong số bảy loài được khảo cứu và công nhận chính thức (Hibbett, 2001; Mata \& Petersen, 2001; Pegler, 1983), nhưng chỉ mới ghi nhận một loài Lentinula edodes (Berk.) Pegler (thu được ở Lào Cai, Cao Bằng và Lâm Đồng) và loài L. lateritia (thu được ở Lạc Dương, Lâm Đồng). Ngoài ra còn có 03 loài Lentinula sp1 (phân bố ở Lâm Đồng), Lentinula sp2 (phân bố Cát Tiên, Đồng Nai) và Lentinula sp3. (phân bố Pù Mát, Nghệ An) (L. H. P. Le, Do, Le, \& Truong, 2010; T. X. Le et al., 2010; Trinh, 1998). Như vậy chính thức chỉ mới có hai loài L. edodes và L. lateritia (Mẫu thu được ở núi Langbiang, Lâm Đồng) là đã được khảo cứu kỹ về hình thái cùng như sinh học phân tử. Các loài khác có nằm trong số 03 loài Lentinula $\mathrm{sp} 1$, Lentinula $\mathrm{sp} 2$ và Lentinula sp3 này hay không? Hay đây là những loài mới trong chi Lentinula? Là những câu hỏi vẫn chưa được giải quyết thỏa đáng. Các loài nấm thuộc chi Lentinula có các đặc điểm hình thái bên ngoài và cả giải phẫu bên trong khá giống nhau. Trong khi ở nấm sự biến đổi hình thái theo môi trường là rất lớn, cho nên để phân biệt các loài mà chỉ dựa vào các đặc điểm hình thái là gần như không thể chính xác. Việc phân loại nhóm nấm hương trở nên càng phức tạp hơn khi các loài trong chi nấm này phân bố trong vùng Úc - Á lại có thể lai được với nhau (Shimomura, Hasebe, Nakai-Fukumasa, \& Kornatsu, 1992).

Các ứng dụng sinh học phân tử để xác định nguồn gốc phát sinh của các loài nấm Hương đã được tiến hành từ những năm 90 . Đa số các công trình đều cho kết quả là có sự tách biệt khá rõ ràng giữa các loài $L$. edodes, L. boryana, L. lateritia, L. novaezelandiae có sự phân chia thành nhóm giữa các mẫu thu được theo các khu vực địa lý rất rõ ràng (Hibbett, 2001; Mata \& Petersen, 2001; Nicholson, Bunyard, \& Royse, 1997). Ở Việt Nam, các mẫu thu được tại núi Langbiang, Vườn Quốc gia Bidoup - Núi Bà, Vườn Quốc gia Cát Tiên đã được xem xét ở mức độ phân tử (L. H. P. Le et al., 2010; T. X. Le et al., 2010). Riêng các mẫu thu được tại Sapa vẫn chưa được giám định mặc dù đã có nhiều báo cáo thu được nấm Hương (Lentinula edodes) ở khu 
vực này (Pham \& Vo, 1995, 1998, 1999 ; Trinh, 1998).

Nấm Hương có thành phần dinh dưỡng cao và hương vị hấp dẫn đặc biệt nên được coi là một loại nấm thực phẩm cao cấp (Crisan \& Sands, 1987; Hui, Wei, \& Liu, 2004; Vetter, 1995). Bên cạnh đó, nấm hương còn có những giá trị y dược đặc sắc như: hoạt tính kháng sinh, hoạt tính chống ung thư, hoạt tính chống virus, tăng cường miễn dịch, hoạt động loại trừ cholesterol ... Do đó, tại các nước như Nhật Bản, Trung Quốc, Hàn Quốc ... nấm Hương đã được nuôi trồng trên quy mô lớn đem lại hiệu quả kinh tế rất cao (Nguyen, 2005). Trong thời gian gần đây ở Việt Nam đã có một số cơ sở sản xuất nấm Hương. Tuy nhiên cho tới nay Việt Nam vẫn phải nhập khẩu một lượng nấm Hương không nhỏ từ Trung Quốc và một lượng nhỏ từ Nhật Bản. Một trong những lý do dẫn đến việc sản xuất nấm Hương tại Việt Nam chưa thực sự phát triển có lẽ là do nấm Hương có thời gian nuôi trồng rất dài và phải trải qua nhiều công đoạn phức tạp trong quy trình nuôi trồng, do vậy rất khó hiện đại hóa, tự động hóa các khâu sản xuất. Công nghệ sản xuất nấm Hương ở các nước có trình độ cao về nuôi trồng nấm như Nhật Bản, Hàn Quốc cũng vẫn phải dựa nhiều vào điều kiện tự nhiên (Chan, 2005). Do vậy yếu tố giống nấm sẽ đóng vai trò rất quan trọng vì chi khi có những chủng giống nấm chất lượng cao, có khả năng thích ứng cao với điều kiện tự nhiên của địa phương thì việc sản xuất loài nấm này mới phát triển thuận lợi được. Như vậy, việc tìm kiếm, sưu tập các nguồn gene bản địa và kiểm định danh pháp của chúng ở mức độ phân tử sẽ rất quan trọng vì chính nó sẽ đặt nền tảng cho công tác lai tạo giống và xây dựng công nghệ sản xuất nấm Hương của nước ta.

Cuối tháng 05 năm 2019, chúng tôi đã thu hái một số quả thể nấm đang phát triển trên các thân cây lá rộng đang mục (Ký hiệu Len026) tại vùng rừng núi xã Sơn Bình, huyện Tam Đường, tỉnh Lào Cai. Các đặc điểm hình thái bên ngoài cho thấy đây là các mẫu nấm thuộc một loài trong chi Lentinula (Earle). Chúng tôi đã tiến hành nghiên cứu này từ nhận định sơ bộ đây là một chủng giống nấm hoang dại quý có tiềm năng dùng làm nguyên liệu cho việc lai tạo ra các chủng nấm nuôi trồng cho địa phương.

\section{2. Đối tượng và phương pháp}

\section{1. Đối tự̛̣ng}

Mẫu nấm ký hiệu Len026 (mẫu có mùi thơm nấm Hương rất nồng) thu hái trên thân cây gỗ lá rộng đang mục, tại khu vực rừng cây lá rộng xã Sơn Bình, huyện Tam Đường, tỉnh Lào Cai vào cuối tháng 05 năm 2019.

\subsection{Phân lập giống thuần}

Một mảnh mô thịt nấm kích thước khoảng $0.5 \times 0.5 \times 0.1 \mathrm{~cm}$ được tách ra từ phần thịt nấm nơi tiếp xúc giữa mũ và cuống nấm, trong điều kiện vô trùng được đưa vào các đĩa Petri $(\Phi 10 \mathrm{~cm})$ chứa môi trường PGA (Potato Glucose Agar) để tạo nguồn giống thuần. Sau khi phân lập, các đĩa này được nuôi ủ ở nhiệt độ $25 \pm 2^{\circ} \mathrm{C}$, trong thời gian 20 ngày. Sau khi kiểm tra giống mẹ được cấy truyền vào các ống nghiệm, nuôi ủ trong cùng điều kiện rồi đưa vào bảo quản ở nhiệt độ $5 \pm 2^{\circ} \mathrm{C}$. Đây chính là nguồn giống phục vụ cho việc tách chiết DNA và các nghiên cứu về đặc điểm sinh trưởng và phát triển của chủng giống nấm này.

\section{3. Định danh}

\subsubsection{Phương pháp so sánh hình thái giải phẫu}

Mẫu quả thể nấm thu được trong tự nhiên được phân tích các đặc điểm hình thái theo phương pháp của Singer (1986). Cấu trúc giải phẫu hiển vi của thể sinh sản, bào tử đảm, liệt bào ... được tiến hành quan sát dưới kính hiển vi quang học (Olympus BX53 - Nhật Bản). Các dẫn liệu 
này được so sánh với các tài liệu tham khảo của các tác giả nước ngoài (Imazeki, Otani, \& Hongo, 1988; Pegler, 1983; Singer, 1986; Teng, 1995). Mẫu vật sau khi định danh được sấy khô và bảo quản tại Viện Nghiên cứu và Ứng dụng Nông nghiệp Công nghệ cao, trường Đại học Đà Lạt.

\subsubsection{Phương pháp sinh học phân tử}

DNA từ hệ sợi nấm được tách chiết bằng phương pháp sử dụng phenol/chloroform, phỏng theo phương pháp của Chomczynski và Sacchi (1987): 01 que gạt hệ sợi được cho vào eppendorf đã có chứa $100 \mu 1$ dung dịch TE $1 \mathrm{X}$, thêm vào $900 \mu \mathrm{l}$ Trizol, pH8. DNA sau đó được tủa bằng Isopropanol với chất trợ tủa GlycoBlue. DNA được giữ trong dung dịch $\mathrm{TE} 1 \mathrm{X}$ (TrisEDTA) và bảo quản ở $-20^{\circ} \mathrm{C}$ cho đến khi sử dụng.

Phản ứng PCR được thực hiện trên máy Mxpro-Mx3005P (Stratagene) với chương trình nhiệt bao gồm $95^{\circ} \mathrm{C}-5^{\prime}$ (1 chu kỳ), 40 chu kỳ lặp lại với $94^{\circ} \mathrm{C}-30^{\prime},, 50^{\circ} \mathrm{C}-30^{\prime},, 72^{\circ} \mathrm{C}-30^{\prime}$ ' và $72^{\circ} \mathrm{C}-5^{\prime}$ (01 chu kỳ). Thể tích hỗn hợp phản ứng là $50 \mu 1$ bao gồm: $1 \times$ dung dịch đệm $\mathrm{PCR}$, $100 \mathrm{nmol} / \mathrm{L}$ mồi, $400 \mu \mathrm{mol} / \mathrm{L}$ mỗi loại dATP, dGTP, dCTP và dTTP, 1.5units hot-start Taq DNA polymerase, $3 \mathrm{mmol} / \mathrm{L} \mathrm{MgCl}_{2}$. Trình tự của hai mồi sử dụng trong phản ứng $\mathrm{PCR}$ (và cũng là phản ứng giải trình tự) như sau: ITS1: TCCGTAGGTGAACCTGCGG và ITS4: TCCTCCGCTTATTGATATGC. Sản phẩm PCR sẽ được phân tích trên gel agarose và sau đó gửi đến công ty Macrogen, Hàn quốc để tinh sạch và giải trình tự. Trình tự này sau đó sẽ được dùng để dò tìm trình tự tương đồng trên ngân hàng dữ liệu gene bằng công cụ BLAST (Basic Local Alignment search tool) (Altschul, Gish, Miller, Myers, \& Lipman, 1990).

\subsubsection{Khảo sát các đặc điểm nuôi trồng}

- Đánh giá khả năng hình thành quả thể và chất lương quả thể trong điều kiện nuôi trồng nhân tạo

Hỗn hợp 400g mạt cưa gỗ cao su, $50 \mathrm{~g}$ cám gạo, $50 \mathrm{~g}$ cám bắp, $7.5 \mathrm{CaCO} 3$ và $1,000 \mathrm{~g}$ nước được cho vào một bịch plastic (polypropylen) sau khi phối trộn kỹ; các bịch được hấp khử trùng ở $96^{\circ} \mathrm{C}$, thời gian 06 giờ. (Chuẩn bị cơ chất và nuôi trồng quả thể theo quy trình công nghệ đang áp dụng tại công ty cổ phần Nguyên Long - Đà Lạt).

- Nuôi ủ hệ sợi

Mỗi bịch cơ chất được cấy khoảng $20 \mathrm{gr}$ giống mẹ làm từ hạt lúa mì trong điều kiện vô trùng. Sau khi cấy giống, các bịch phôi được nuôi trong phòng ủ tơ có nhiệt độ ban đêm $15 \pm$ $2^{\circ} \mathrm{C}$; nhiệt độ ban ngày $25 \pm 2^{\circ} \mathrm{C}$ cho tới khi hệ sợi xâm chiếm toàn bộ khối cơ chất.

\section{- Nâu hóa bịch phôi}

Phôi nấm sau khi được lột bỏ lớp túi plastic được chuyển sang phòng ra quả thể ở chế độ tối/sáng tự nhiên với cường độ ánh sáng tối đa khoảng 500lux, ẩm độ không khí duy trì trên $80 \%$. Nhiệt độ $25 \pm 2^{\circ} \mathrm{C}$. Quan sát và đánh giá quá trình nâu hóa của các bịch phôi.

\section{- Ra quả thể}

Quá trình hình thành quả thể được tiến hành trong điều kiện nhiệt độ ban ngày $25 \pm 2^{\circ} \mathrm{C}$, nhiệt độ ban đêm $15 \pm 2{ }^{\circ} \mathrm{C}$ và ẩm độ không khí duy trì ở 85-95\%.

Các thông số kỹ thuật được xác định thông qua thời gian hệ sợi xâm chiếm toàn bộ cơ chất; thời gian hóa nâu; thời gian hình thành mầm quả thể; số lượng mầm nấm/ bịch; tỷ lệ mầm nấm phát triển tới trưởng thành/ số mầm nấm; năng suất bịch phôi; tỷ lệ quả thể theo kích thước và trọng lượng. 


\section{Kết quả và thảo luận}

\section{1. Định danh}

Đặc điểm hình thái giải phẫu: Mẫu nấm Len026 mọc rời rạc trên thân gỗ mục của cây lá rộng phủ đầy rêu (Hình $1 \mathrm{~A}$ ). Mũ nấm có màu nâu sậm khi ướt, chuyển sang nâu nhạt khi khô, có các vảy sợi thô màu trắng, lồi nhẹ khi còn non, phẳng dần khi trưởng thành, mép mũ mỏng dễ rách $(H i ̀ n h ~ 1 \mathrm{~B}, 1 \mathrm{C})$; Kích thước mũ nấm $2.5-2.0 \mathrm{~cm}$; Bào tầng dạng phiến, đính rời, màu trắng (Hình 2); Cuống nấm kích thước: $0.6-1.5 \mathrm{~cm} \times 3-5 \mathrm{~cm}$; đính giữa hoặc hơi lệch tâm, hình trụ, đặc chắc, màu trắng ở phần trên cao, màu nâu ở sát phần giá thể. Mặt cuống có vảy thô; Tồn tại vòng nấm rất mờ, dạng sợi tơ. Chất thịt màu trắng, mềm, thịt mũ nấm mỏng $0.3 \mathrm{~cm}$, dai, cấu tạo bởi lớp sợi kết hợp khá lỏng lẻo, thường phân nhánh và có khóa ở hầu hết các vách ngăn. Bào tử màu trắng, bầu dục đến hơi elip, trong suốt không chứa tinh bột, không chứa đường dextro, vách mỏng nhẵn, với một vài hạt bên trong, thuôn thành mấu nhỏ ở đầu bào tử phần tiếp xúc với tiểu bính. Kích thước: 3-3.5 × 5-6 $\mu \mathrm{m}$. Đảm dạng chùy hẹp, mang 04 tiểu bính. Các liệt bào cạnh (pleurocystidia) dạng chày phình to, trong suốt. Liệt bào đỉnh (cheilocystidia) dạng quả lê hoặc dạng chày phình to có chóp nhọn.

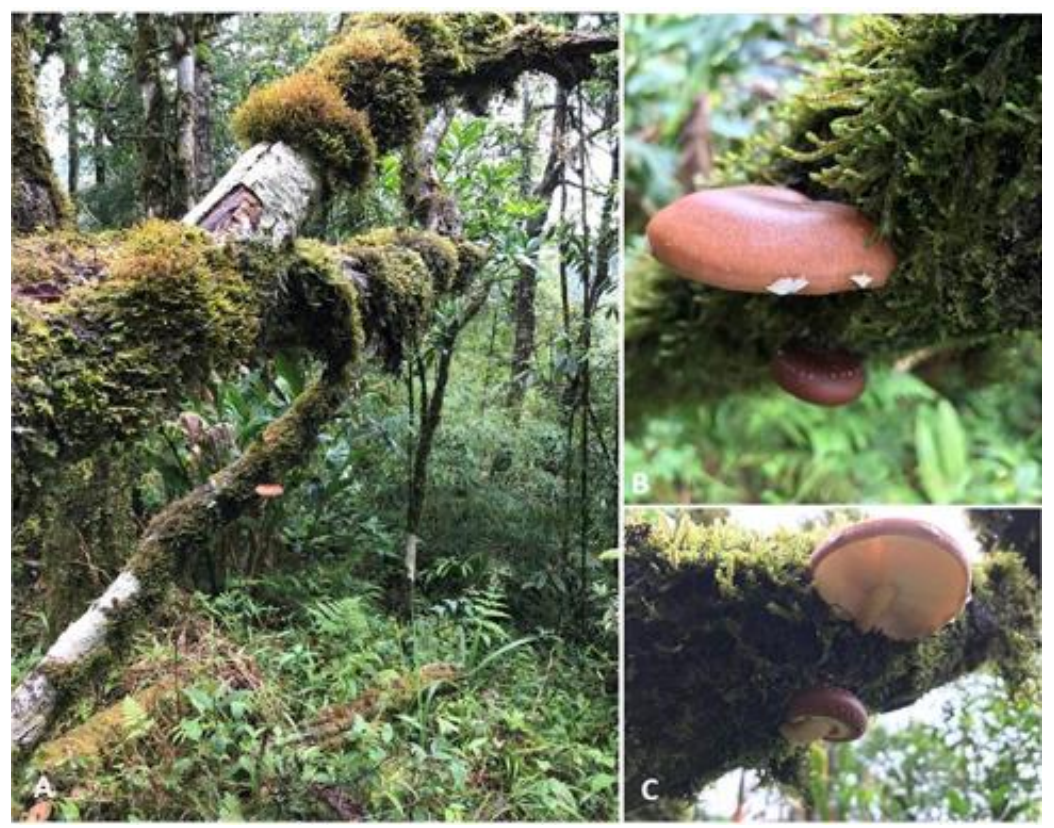

Hình 1. Nấm Hương Sapa trong tự nhiên A. Sinh cảnh nơi thu mẫu; B. mặt trên mũ nấm, với các vảy màu trắng; $\mathrm{C}$. thụ tầng dạng phiến 


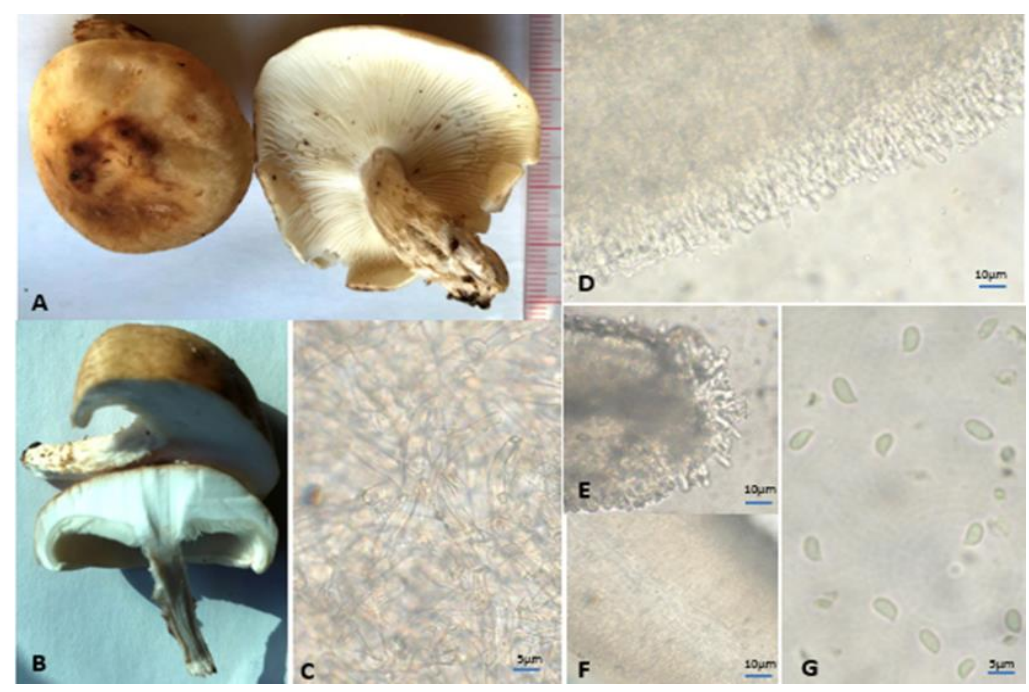

Hình 2. Giải phẫu quả thể nấm Hương Sapa, A Quả thể; B Bào tầng dạng phiến; C Cấu trúc hệ sợi thịt mũ nấm; D Đảm; E Cheilocystidia; F Cấu trú hệ sợi song song ở chất nền bào tầng;

$\mathrm{G}$ Bào tử đảm

\subsection{Phân tích phả hệ học dụa trên vùng trình tụ̂ ITS1, 5.8S, ITS2}

Cơ sở dữ liệu được xây dựng thông qua việc thu thập các trình tự tham chiếu các loài thuộc chi Lentinula trên cơ sở dữ liệu genbank (NCBI, n.d.). Nhóm ngoại được sử dụng là trình tự loài Marasmiellus foliiplilus (thuộc chi Marasmiellus). Các trình tự tham chiếu được trình bày ở Bảng 1.

\section{Bảng 1}

Danh sách các chủng nấm sử dụng để dựng cây phả hệ và mã số gia nhập (accession number) trên ngân hàng gene

\begin{tabular}{|l|c|c|c|}
\hline \multicolumn{1}{|c|}{ Loài } & Chủng & Mã số truy cập & Ghi chú \\
\hline Lentinula edodes & STCL-125 & AF031183 & Trung Quốc \\
\hline Lentinula edodes & STCL-140 & AF031184 & Trung Quốc \\
\hline Lentinula edodes & VB-361 & AF031189 & Hàn Quốc \\
\hline Lentinula edodes & VB-355 & AF031190 & Hàn Quốc \\
\hline Lentinula edodes & TMI1546 & AF031191 & Nepal \\
\hline Lentinula boryana & IE 17/R38 & AF031176 & \\
\hline Lentinula boryana & IE 154/R50 & AF031177 & \\
\hline Lentinula raphanica & FLAS-F-61499 & MH211931 & \\
\hline Lentinula raphanica & FLAS-F-61820 & MH212103 & \\
\hline Lentinula aciculospora & PPN-ag-001 & JQ247977 & \\
\hline Marasmiellus foliiplilus & CUH AM090 & KP317637 & \\
\hline Marasmiellus foliiplilus & CUH AM090 & NR154176 & \\
\hline
\end{tabular}

Nguồn: Dữ liệu thu nhận trên ngân hàng Genbank (NCBI, n.d.) 
Mô hình tiến hóa T92+G được áp dụng cho việc xây dựng cây phả hệ phân tử Maximum likelihood với giá trị bootstrap lặp lại 1,000 lần. Kết quả cây phả hệ phân tử được trình bày ở hình sau:

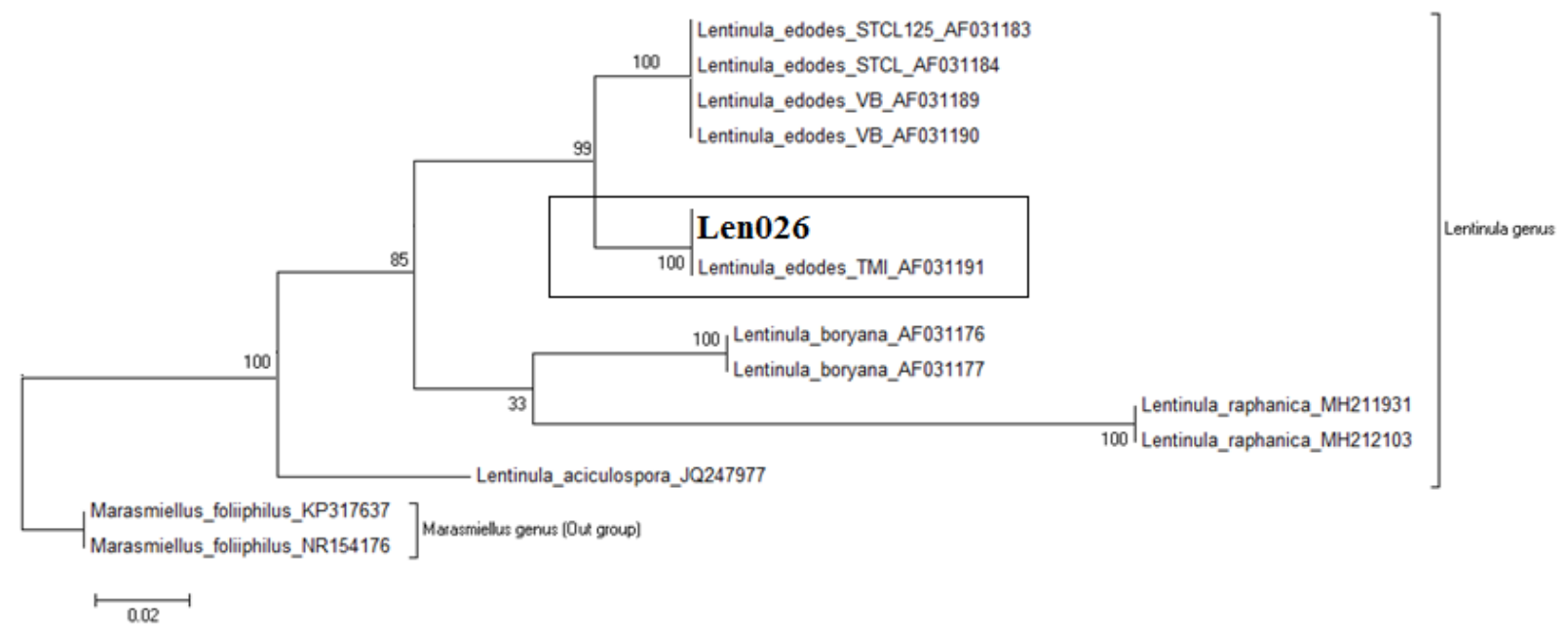

Hình 3. Kết quả phân tích phả hệ mẫu Len026

Dựa trên kết quả phân tích phả hệ phân tử, các mẫu thực nghiệm đều phân nhóm với loài Lentinula edodes (với giá trị bootstrap đạt $99 \%$ ) và tách biệt với các loài khác trong chi Lentinula. Đồng thời, chi này hoàn toàn tách biệt với trình tự loài Marasmiellus foliiplilus (thuộc chi Marasmiellus) - nhóm ngoại.

Xét riêng nhóm Lentinula edodes, mẫu Len026 hình thành nhóm đơn (monophyletic group) với trình tự tham chiếu Lentinula edodes có nguồn gốc từ Nepal với giá trị bootstrap $100 \%$.

Như vậy, điều này gợi ý rằng mẫu Len026 tương đồng với mẫu Lentinula edodes có nguồn gốc từ Nepal.

\subsection{Nấm hương chủng giống Len026 nuôi trồng trên môi trương nhân tạo}

Trên cơ chất mùn cưa cây cao su có bổ sung dinh dưỡng, Len026 phát triển khá nhanh, thời gian hệ sợi xâm chiếm toàn bộ bịch cơ chất $1.4 \mathrm{~kg}$ trong khoảng 79 ngày (bịch mọc nhanh nhất) đến 85 ngày (bịch mọc chậm nhất) (Hình 4A, 4B).

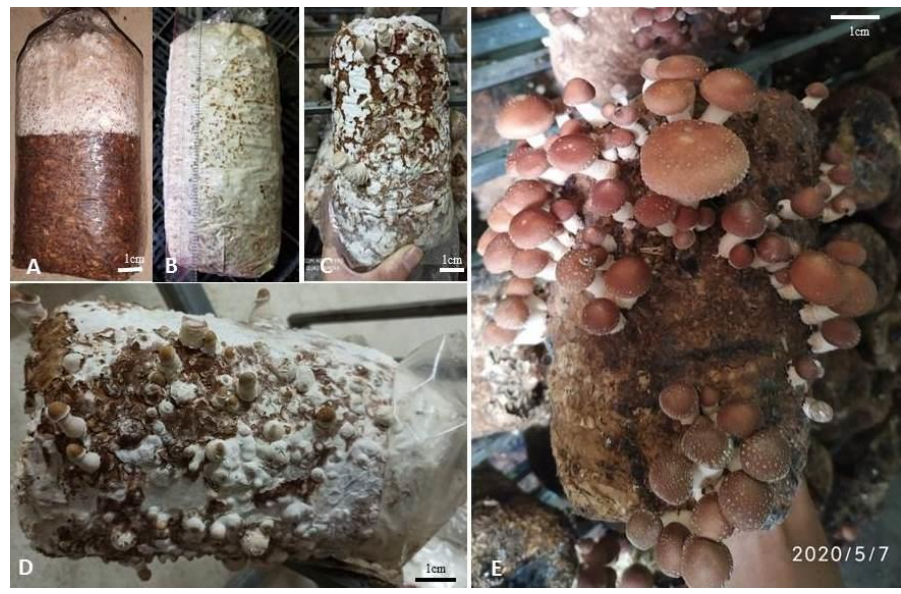

Hình 4. Các giai đoạn phát triển của Len026: A. Hệ sợi sau 35 ngày; B. Hệ sợi sau 80 ngày; C, D. Mầm quả thể xuất hiện ngay trong quá trình nâu hóa; E. Quả thể Len026 
Sau khi hệ sợi vừa xâm chiếm toàn bộ khối cơ chất, mặc dù vẫn chưa mở bịch thì đã xuất hiện các điểm nâu hóa phân bố khá đều trên toàn bộ bề mặt bịch cơ chất (Hình 4C). Len026 hóa nâu khá nhanh và dễ dàng trong khoảng thời gian 22-25 ngày.

\section{Bảng 2}

Một số thông số kỹ thuật nuôi trồng chủng nấm Hương Sapa trên cơ chất mùn cưa cao su

\begin{tabular}{|l|c|c|c|}
\hline \multicolumn{1}{|c|}{ Chủng giống } & $\begin{array}{c}\text { Thời gian phủ kín co } \\
\text { chất (ngày) }\end{array}$ & $\begin{array}{c}\text { Thời gian hóa nâu } \\
\text { (ngày) }\end{array}$ & $\begin{array}{c}\text { Thời gian ra quả } \\
\text { thể (ngày) }\end{array}$ \\
\hline Len026 & $82 \pm 3$ & $20-22$ & $5-6$ \\
\hline
\end{tabular}

Nguồn: Tác giả quan sát và thu thập

Mầm nấm xuất hiện ngay trong quá trình nâu hóa. Kể từ khi mở bịch đề hệ sợi nấm tiếp xúc không khí thì 05-06 ngày sau các mầm nấm đã bắt đầu xuất hiện với số lượng rất lớn.

Các mầm nấm đều phát triển đến trưởng thành đạt hiệu suất sinh học là $27.73 \%$. Tuy nhiên kích thước nấm rất nhỏ, số quả thể có kích thước $<1.5 \mathrm{~cm}$ chiếm đến $65.7 \%$; nấm có kích thước từ $1.5 \mathrm{~cm}-2.5 \mathrm{~cm}$ chiếm $17.3 \%$ trong khi nấm có đường kính mũ $>2.5 \mathrm{~cm}$ chỉ chiếm $17 \%$ (Bảng 3). Chất lượng chủng giống nấm Len026 khá thấp khi thể hiện qua tỷ lệ nấm có trọng lượng $>10 \mathrm{~g} /$ quả thể chiếm tỷ lệ rất thấp $(5 \%)$ (Bảng 3$)$.

\section{Bảng 3}

Phân loại chất lượng quả thể nấm

\begin{tabular}{|c|c|c|c|c|c|c|c|}
\hline \multirow[b]{2}{*}{$\begin{array}{l}\text { Chủng } \\
\text { giống }\end{array}$} & \multicolumn{3}{|c|}{ Tỷ lệ theo đường kính mũ (\%) } & \multicolumn{3}{|c|}{$\begin{array}{c}\text { Tỷ lệ theo trọng lượng } \\
(\%)\end{array}$} & \multirow[b]{2}{*}{$\begin{array}{c}\text { Năng suất trung } \\
\text { bình }\end{array}$} \\
\hline & $<1.5(\mathrm{~cm})$ & $\begin{array}{c}1.5-2.5 \\
(\mathrm{~cm})\end{array}$ & $\begin{array}{c}> \\
2.5(\mathrm{~cm}) \\
{[\mathrm{A} 1]} \\
{[\mathrm{A} 1]}\end{array}$ & $<5 g$ & $5-10 g$ & $>10 \mathrm{~g}$ & \\
\hline Len026 & 65.7 & 17.3 & 17.0 & 71.8 & 23.2 & 5.0 & $138.65 \pm 3.11$ \\
\hline
\end{tabular}

Nguồn: Tác giả quan sát và tổng hợp

\section{Kết luận}

Qua giải phẫu hình thái và phân tích sinh học phân tử cho thấy mẫu nấm Lentinula thu thập được tại Lào Cai chính là một chủng nấm hương thuộc loài Lentinula edodes, thuộc chi Lentinula Earle, họ Marasmiaceae, bộ Agaricales.

Chủng giống Len026 có khả năng phát triển tốt trong điều kiện nuôi trồng nhân tạo và có nhiều đặc điểm ưu việt như thời gian phát triển hệ sợi ngắn, thời gian hóa nâu bịch phôi ngắn, khả năng hình thành mầm nấm cao và dễ dàng, tỉ lệ nấm non phát triển tới trưởng thành cao ... là những tính chất có thể tận dụng để phục vụ cho công nghệ nuôi trồng nấm. Đây thực sự là một nguồn gene bản địa quý trong công tác lai tạo các chủng giống sản xuất thích nghi cao với điều kiện nuôi trồng địa phương.

\section{LÒ̀I CÁM ONN}

Chúng tôi xin cảm ơn Ban Quản lý Khu Nông nghiệp Công nghệ cao Thành phố Hồ Chí Minh và Chương trình phát triển nông nghiệp ứng dụng công nghệ cao trên địa bàn Thành phố 
giai đoạn 2016-2020, định hướng đến năm 2025 (Quyết định số 6510/QĐ-UBND ngày 24/11/2016) đã tài trợ nghiên cứu này.

\section{Tài liệu tham khảo}

Altschul, S. F., Gish, W., Miller, W., Myers, E. W., \& Lipman, D. J. (1990). Basic local alignment search tool. Journal of Molecular Biology, 215(3), 403-410.

Chan, A. W. (2005). Shiitake bag cultivation. In Mushroom growers handbook 2. Seoul, Korea: MushWorld.

Chomczynski, P., \& Sacchi, N. (1987). Single-step method of RNA isolation by acid guanidinium thiocyanate-phenol-chloroform extraction. Analytical Biochemistry, 162(1), 156-159.

Crisan, E. V., \& Sands, A. (1987). Nutritional value. In S. Chang \& W. A. Hayes (Eds.), The Biology and Cultivation of Edible Mushroom (pp. 137-165). London, UK: Academic Press.

Hibbett, D. S. (2001) Shiitake mushrooms and the molecular clocks: Historical biogeography of Lentinula. Journal of Biogeography, 28, 231-241.

Hui, F. L., Wei, M. H., \& Liu, Z. H. (2004). Assay study on amino acid, trace elements and toxic heavy metals of the fruit bodies of Lentinus edodes. Shipin Kexue (Beijing, China), 25, 161-163.

Imazeki, R., Otani, Y., \& Hongo, T. (1988). Fungi of Japan. Tokyo, Japan: Yama-kei Publishers Co., Ltd.

Le, L. H. P., Do, L. T. T., Le, T. H. A., \& Truong, N. B. (2010). Nghiên cứu một số đặc điểm sinh học của chủng nấm hương Lentinula edodes hoang dại, mới phát hiện tại núi Langbian, Đà Lạt [A study on biological characteristics of wild shiitake mushroom strain Lentinula edodes, newly found in Mount LangBiang, Dalat City]. Tạp Chí Công Nghệ Sinh Hoc, 8(3B), 1397-1404.

Le, T. X., Nguyen, H. L. Q., Truong, H. T., Hoang, H. T., Pham, D. N., Truong, N. B., \& Dao, L. T. (2010). Nghiên cứu đa dạng của các loài nấm Hương Lentinula edodes ở Sapa, Lentinula cf. lateritia ở Langbian, Đà Lạt và Lentinula sp. mới tìm thấy ở Cát Tiên, Việt Nam [Study on the diversity of shiitake Lentinula edodes species in Sapa, Lentinula cf. lateritia in Langbiang, Da Lat and Lentinula sp., newly discovered in Cat Tien, Vietnam]. Tạp chi Công Nghệ Sinh Học, 8(1), 87-101.

Mata, J. L., \& Petersen, R. H. (2001). Type specimen studies of New World Lentinula. Mycotaxon, 79, 217-229.

NCBI. (n.d.). Gene. Retrieved March 18, 2021, from https://www.ncbi.nlm.nih.gov/gene

Nguyen, D. L. (2005). Công nghệ nuôi trồng nấm [Mushroom farming technology]. Hanoi, Vietnam: Nhà xuất bản Nông nghiệp.

Nicholson, M. S., Bunyard, B. A., \& Royse, D. J. (1997). Phylogeny of the genus Lentinula based on ribosomal DNA restriction fragment length polymorphism analysis. Mycologia, 89(3), 400-407.

Pegler, D. N. (1983). The genus Lentinula (Tricholomataceae tribe Collybieae). Sydowia, 36, 227-239. 
Pham, H. T., \& Vo, K. T. P. (1995). Trồng nấm hương Lentinula edodes phân lập tại Cao Bằng [Growing shiitake Lentinula edodes isolated in Cao Bang]. Kỷ yếu hội nghị Khoa học trường ĐH Tổng hợp Tp. HCM, 595-601.

Pham, H. T., \& Vo, K. T. P. (1998). Lai nấm hương Lentinula edodes Cao Bằng với chủng nấm hương nhập từ Nhật [Hybridization of Lentinula edodes Cao Bang with a strain of shiitake imported from Japan]. Di truyền hoc và ứng dụng, 1, 1-6.

Pham, H. T., \& Vo, K. T. P. (1999). Lai nấm hương Lentinula edodes giữa chủng Cao Bằng và chủng L170 nhập nội [Hybridization of Lentinula edodes between Cao Bang strain and imported L170 strain]. Di truyền học và úng dụng, 4, 15-19.

Shimomura, N., Hasebe, K., Nakai-Fukumasa, Y., \& Kornatsu, M. (1992). Intercompatibility between geographically distant strains of Shiitake (Reports of the Tottori Mycological Institute, No. 30). Retrieved May 10, 2021, from Food and Agriculture Organization website https://agris.fao.org/agris-search/search.do?recordID=JP9400985

Singer, R. (1986). The agaricales in modern taxonomy (4th ed.). Koenigstein, Germany: Koeltz Scientific Books.

Teng, S. C. (1995). Fungi of China. New York, NY: Mycotaxon, LTD.

Trinh, K. T. (1998). Danh lục nấm lón Việt Nam [List of large mushrooms in Vietnam]. Hanoi, Vietnam: Nhà xuất bản Nông nghiệp.

Vetter, J. (1995). Mineral and amino acid contents of edible, cultivated mushroom Shiitake (Lentinus edodes). Zeitschrift fuer Lebensmittel - Unterssuchung und Forschung, 201, 1719. 